\title{
Karakteristik Pasien Disfonia di Poliklinik Telinga Hidung Tenggorok-Bedah Kepala Leher RSUP DR. M. Djamil Padang Tahun 2010-2013
}

\author{
Aini Gusmarina ${ }^{1}$, Novialdi ${ }^{2}$, Hardisman $^{3}$
}

\begin{abstract}
Abstrak
Disfonia merupakan suatu gejala dari kelainan laring. Bagian IImu Kesehatan Telinga Hidung Tenggorok-Bedah Kepala Leher (THT-KL) RSUP Dr. M. Djamil Padang belum memiliki data empiris terkait karakteristik kelainan ini. Tujuan penelitian ini adalah menentukan karakteristik pasien disfonia di bagian IImu Kesehatan THT-KL RSUP Dr. M.Djamil Padang. Data penelitian diambil dari rekam medis dengan metode total sampling. Karakteristik pasien disfonia yang dicatat mencakup usia, jenis kelamin, gejala klinik, etiologi disfonia, dan gambaran pemeriksaan laring. Total 68 dari 119 pasien memenuhi kriteria untuk dijadikan sampel penelitian. Hasil penelitian menunjukkan kelompok usia tertinggi pasien disfonia berada pada kelompok usia 40-49 tahun (29,5\%).Jumlah pasien laki-laki dan perempuan adalah sebanding (1:1).Laryngopharyngeal Reflux (LPR) (33,8\%) didapatkan sebagai etiologi tertinggi. Gambaran kelainan terbanyak yang ditemukan pada pemeriksaan laringoskopi adalah hiperemis pada epiglotis (14,7\%), edema pada aritenoid $(69,1 \%)$, massa pada plika vokalis $(13,2 \%)$, dan edema pada plika ventrikularis $(17,6 \%)$. Simpulan studi ini adalah LPR merupakan etiologi tertinggi pasien disfonia. Pengetahuan tentang kondisi ini dapat meningkatkan diagnosis dan keberhasilan pengobatan pasien disfonia.
\end{abstract}

Kata kunci: disfonia, kelainan laring, karakteristik

\begin{abstract}
Dysphonia is a symptom of laryngeal abnormality. Department of Ear Nose Throat-Head and Neck Surgery General Hospital DR. M. Djamil Padang doesn't have empirical data related to the characteristics of this abnormality. The objective of this study was to determine the characteristics of dysphonia patients in the department in the period of 2010-2013. The data was conducted from the medical record by employing total sampling method. All characteristics of the patients was recorded, such as age, gender, clinical symptoms, etiologies of dysphonia, and visualization of laryngeal examination. Total 68 out of 119 patients meet the requirement of research criteria. The results showed that majority of the patients are from age group of 40-49 years (29.5\%). Meanwhile, the ratio of male and female patients is balance (1:1). Laryngopharyngeal Reflux (LPR) (33.8\%) is the main etiology of dysphonia. The most common visualization of laryngeal examination in the epiglottis is hyperemis (14.7\%), in the arytenoids is edema (69,1\%), in the vocal cords is mass (13.2\%), and in the fold ventrikularis is edema (17.6\%). In conclusion, LPR is the most common etiology of dysphonia patients. Knowledge about these conditions may improve diagnosis and treatment of dysphonia patients.
\end{abstract}

Keywords: dysphonia, laryngeal abnormality, characteristics

Affiliasi penulis: 1. Prodi Profesi Dokter FK Unand (Fakultas Kedokteran Universitas Andalas Padang) 2. Bagian Telinga Hidung Tenggorok-Bedah Kepala Leher FK Unand 3. Bagian IImu Kesehatan Masyarakat FK Unand

Korespondensi: Aini Gusmarina, Email: gusmarinaini@gmail.com , Telp: 081298686003

\section{PENDAHULUAN}

Gangguan suara atau suara serak (disfonia) didefinisikan sebagai gangguan yang ditandai dengan perubahan kualitas vokal, pitch, kenyaringan atau usaha vokal yang mengganggu komunikasi atau mengurangi kualitas hidup yang berhubungan dengan penggunaan suara. ${ }^{1}$ Disfonia bukanlah suatu penyakit melainkan gejala kelainan pada laring yang dapat disebabkan oleh perubahan patologis dari proses infeksi dan inflamasi, kondisi neuromuskuler dan kejiwaan, gangguan sistemik, dan neoplasma. Pemeriksaan laringoskopi sebagai bagian penting 
dalam pemeriksaan lengkap di bagian IImu Kesehataan Telinga Hidung Tenggorok-Bedah Kepala Leher yang dibutuhkan dalam membantu menegakkan diagnosis definitf. ${ }^{2,3}$

Studi epidemiologi mendapatkan bahwa di Inggris sekitar 40.000 pasien dengan disfonia dirujuk ke pusat terapi suara tiap tahunnya. ${ }^{4}$ Cohen et alpada tahun 2012 mendapatkan prevalensi keseluruhan disfonia dari objek yang diteliti adalah sebesar 0,98\% dengan populasi perempuan $63,4 \%$ dan laki-laki $36,5 \%$. Prevalensi tertinggi tercatat pada laki-laki dibanding perempuan pada usia 0-9 tahun, diikuti dengan prevalensi tertinggi tercatat pada perempuan dibanding laki-laki mulai pubertas sampai usia $>70$ tahun. ${ }^{5}$

Penelitian Haryuna pada tahun 2009 mendapatkan bahwa keganasan laring adalah yang paling banyak dijumpai, yaitu 21 penderita (19,6\%), diikuti oleh parese/paralisa pita suara pada 18 penderita $(16,8 \%)$, dan nodul pita suara pada 13 penderita (12,1\%). Gambaran pemeriksaan laringoskopi terbanyak yang ditemukan pada pasien disfonia dengan etiologi tuberkulosis laring adalah edema dan hiperemis pada epiglotis $(66,7 \%)$, aritenoid (50\%), dan plika vesibularis $(66,7 \%)$. Pada plika vokalis jenis lesi terbanyak adalah ulserasi $(60 \%)$. Pada plika ariepiglotika hanya dijumpai jenis lesi granulomatous. ${ }^{6}$

Roy et al (2007) mendapatkan variasi keluhan penderita gangguan suara, antara lain suara serak, suara desah, suara goyah atau gemetar, suara hilang atau afonia, seperti ada cairan saat bersuara, sering mendehem, tidak nyaman dalam menggunakan suara, hanya bisa mengeluarkan suara pada satu frekuensi saja atau monoton, ada upaya berlebih untuk berbicara, sulit menelan, tenggorok terasa kering yang kronis, dan sakit tenggorok. ${ }^{7}$

Informasi epidemiologi yang valid dan dapat diandalkan terkait gangguan suara (disfonia) akan sangat berguna untuk merencanakan masa depan penyediaan layanan kesehatan. Beberapa prevalensi data yang ada terbatas hanya pada kelompokkelompok tertentu pengguna suara profesional (penyanyi, guru, dan penceramah). ${ }^{8}$
Berdasarkan keterangan di atas, banyak hal yang menyebabkan disfonia menjadi penting untuk diteliti. Keluhan dan etiologi penyebab disfonia yang bervariasi menyebabkan dibutuhkannya pemeriksaan laringoskopi untuk menegakkan diagnosis definitif sehingga penatalaksaan penyakit dapat dilakukan berdasarkan etiologi yang mendasari.

Sepanjang penelusuran pustaka di Bagian IImu Kesehatan Telinga Hidung Tenggorok-Bedah Kepala Leher (THT-KL) RSUP DR. M. Djamil Padang belum memiliki data empiris terkait karakteristik pasien disfonia secara keseluruhan. Oleh karena itu perlu diteliti tentang bagaimana karakteristik pasien disfonia di Poliklinik Telinga Hidung TenggorokBedah Kepala Leher RSUP DR. M. Djamil Padang.

\section{METODE}

Desain penelitian ini adalah deskriptif retrospektif. Penelitian dilakukan dari Oktober 2013Desember 2014 dengan mengambil data rekam medik pasien disfonia dari tahun 2010-2013 di Bagian Instalasi Rekam Medik RSUP DR. M. Djamil Padang.

Populasi adalah semua pasien disfonia yang berobat di Poliklinik Telinga Hidung Tenggorok-Bedah Kepala Leher (THT-KL) RSUP DR. M. Djamil Padang sesuai data rekam medik tahun 2010-2013. Pengambilan sampel dilakukan dengan teknik total sampling, yaitu seluruh populasi dijadikan sampel dengan memperhatikan kriteria inklusi dan eksklusi.

Analisis data dilakukan terhadap tiap variabel dari hasil penelitian untuk melihat distribusi frekuensi meliputi usia, jenis kelamin, gejala klinik, etiologi disfonia, dan gambaran pemeriksaan laring.

\section{HASIL}

Pasien disfonia yang memenuhi kriteria untuk dijadikan sampel penelitian adalah sebesar 68 pasien dari total 119 kasus.

Tabel 1. Jumlah kasus disfonia tahun 2010-2013

\begin{tabular}{ccc}
\hline Tahun & $(\mathbf{n = 6 8 )}$ & $\%$ \\
\hline 2010 & 7 & 10,3 \\
2011 & 17 & 25 \\
2012 & 30 & 44,1 \\
2013 & 14 & 20,6 \\
\hline Total & 68 & 100 \\
\hline
\end{tabular}


Pada Tabel 1 dapat dilihat bahwa frekuensi tertinggi kasus disfonia berada pada tahun 2012 dengan jumlah 30 pasien $(44,1 \%)$.

Tabel 2. Distribusi frekuensi pasien disfonia berdasarkan usia

\begin{tabular}{ccc}
\hline Umur & $\mathbf{n = 6 8}$ & $\%$ \\
\hline 0-9 tahun & 1 & 1,5 \\
10-19 tahun & 3 & 4,4 \\
20-29 tahun & 9 & 13,2 \\
30-39 tahun & 9 & 13,2 \\
40-49 tahun & 20 & 29,5 \\
50-59 tahun & 9 & 13.2 \\
60-69 tahun & 5 & 7,4 \\
>70 tahun & 12 & 17,6 \\
\hline Total & 68 & 100 \\
\hline
\end{tabular}

Tabel 2 menggambarkan bahwa frekuensi tertinggi pasien disfonia berada pada kelompok usia 40-49 tahun sebanyak 20 pasien $(29,5 \%)$.

Tabel 3. Distribusi frekuensi pasien disfonia berdasarkan jenis kelamin

\begin{tabular}{ccc}
\hline Jenis Kelamin & $\mathbf{n = 6 8}$ & $\%$ \\
\hline Laki-laki & 34 & 50 \\
Perempuan & 34 & 50 \\
\hline Total & 68 & 100 \\
\hline
\end{tabular}

Berdasarkan Tabel 3, dapat diketahui bahwa jumlah pasien disfonia laki-laki dan perempuan adalah sama banyak, yaitu 34 pasien masing-masing $(50 \%)$

Tabel 4. Distribusi frekuensi pasien disfonia berdasarkan gejala klinik

\begin{tabular}{ccc}
\hline Gejala Klinik & $\mathbf{n = 6 8}$ & $\mathbf{\%}$ \\
\hline Suara Serak & 68 & 100 \\
Batuk Berdahak & 24 & 35,3 \\
Nyeri Menelan & 13 & 19,1 \\
Sesak Napas & 8 & 11,8 \\
Demam & 6 & 8,8 \\
Bengkak di Leher & 3 & 4,4 \\
\hline
\end{tabular}

Tabel 4 menggambarkan bahwa gejala klinik tertinggi yang diderita oleh pasien disfonia adalah suara serak dengan jumlah 68 pasien (100\%).
Tabel 5. Distribusi frekuensi pasien disfonia berdasarkan etiologi

\begin{tabular}{ccc}
\hline Etiologi & $\mathbf{n = 6 8}$ & $\mathbf{\%}$ \\
\hline LPR & 23 & 33,8 \\
Paralisis Pita Suara & 16 & 23,5 \\
TB Laring & 7 & 10,3 \\
Laringitis Kronis & 6 & 8.8 \\
Tumor Laring & 6 & 8,8 \\
Laringitis Akut & 5 & 7.4 \\
Lesi Jinak Pita Suara & 2 & 2,9 \\
Trauma Laring & 1 & 1,5 \\
Miastenia Gravis & 1 & 1,5 \\
Disfonia spasmodik & 1 & 1,5 \\
\hline Total & 68 & 100 \\
\hline
\end{tabular}

Tabel 5 menunjukkan bahwa etiologi tertinggi yang didapatkan pada pasien disfonia adalah Laryngopharyngeal Reflux (LPR) sebanyak 23 pasien $(33,8 \%)$.

Tabel 6. Distribusi frekuensi gambaran pemeriksaan laring pasien disfonia

\begin{tabular}{|c|c|c|c|}
\hline $\begin{array}{c}\text { Pemeriksaan } \\
\text { Laring }\end{array}$ & Hasil & $F(n=68)$ & $\%$ \\
\hline \multirow{4}{*}{$\begin{array}{c}\text { Laring } \\
\text { Epiglotis }\end{array}$} & Tenang & 56 & 82,4 \\
\hline & Hiperemis & 10 & 14,7 \\
\hline & Edema & 4 & 5,9 \\
\hline & Massa & 2 & 2,9 \\
\hline \multirow[t]{4}{*}{ Aritenoid } & Tenang & 13 & 19,1 \\
\hline & Hiperemis & 35 & 51,5 \\
\hline & Edema & 47 & 69,1 \\
\hline & Massa & 4 & 5,9 \\
\hline \multirow[t]{5}{*}{ Plika Vokalis } & Simetris & 51 & 75 \\
\hline & Asimetris & 17 & 25 \\
\hline & Hiperemis & 5 & 7,4 \\
\hline & Edema & 6 & 8,8 \\
\hline & Massa & 9 & 13,2 \\
\hline \multirow[t]{4}{*}{ Plika Ventrikulari } & Tenang & 54 & 79,4 \\
\hline & Hiperemis & 7 & 10,3 \\
\hline & Edema & 12 & 17,6 \\
\hline & Massa & 4 & 5,9 \\
\hline \multirow[t]{2}{*}{ Rima Glotis } & Terbuka & 67 & 98,5 \\
\hline & Tertutup & 1 & 1,5 \\
\hline \multirow[t]{2}{*}{ Sinus Piriformis } & Positif & 6 & 8,8 \\
\hline & Negatif & 62 & 91,2 \\
\hline
\end{tabular}

Tabel 6 menggambarkan hasil pemeriksaan laring pada epiglotis dan plika ventrikularis terbanyak adalah tenang, yaitu 56 pasien $(82,4 \%)$ pada epiglotis 
dan 54 pasien $(79,4 \%)$ pada plika ventrikularis. Pada aritenoid didapatkan edema pada 47 pasien $(69,1 \%)$. Pergerakan simetris plika vokalis didapatkan pada 51 pasien (75\%) dan asimetris pada 17 pasien (25\%). Pada plika vokalis gambaran kelainan terbanyak adalah massa pada 9 pasien (13,2\%). Rima glotis didapatkan terbuka pada 67 pasien (98,5\%) dan standing secretion negatif (-) sinus piriformis pada 62 pasien $(91,2 \%)$ didapatkan sebagai gambaran pemeriksaan laring terbanyak.

\section{PEMBAHASAN}

Usia pasien disfonia yang didapatkan pada penelitian ini bervariasi dari 9-80 tahun. Berdasarkan kelompok usia, didapatkan hasil bahwa frekuensi tertinggi berada pada kelompok usia 40-49 tahun sebesar 20 pasien (29,5\%), diikuti oleh kelompok usia $>70$ tahun sebesar 12 pasien (17,6\%), dan terendah berada pada kelompok usia 0-9 tahun sebesar 1 pasien $(1,5 \%)$.

Penelitian Hojna et al tahun 2004 mendapatkan rata-rata usia penderita disfonia pada kelompok pekerja pertama (guru taman kanak-kanak, guru sekolah dasar, guru menengah pertama, guru menengah atas, pengacara, jaksa, hakim, dan pemain film) adalah 43 tahun untuk laki-laki dan 45 tahun untuk perempuan, sedangkan pada kelompok pekerja kedua (pekerjaan lain yang tidak termasuk pada kelompok pekerja pertama) adalah 45 tahun untuk laki-laki dan 42 tahun untuk perempuan. ${ }^{9}$

Aghadoost et al (2013) juga mendapatkan hasil serupa yaitu rata-rata umur guru perempuan yang menderita gangguan suara adalah $44,5 \pm 3.55$ tahun. $^{10}$ Penelitian Kiakojoury et al (2014) juga mendapatkan prevalensi tertinggi gangguan suara (disfonia) adalah pada usia $<45$ tahun. ${ }^{11}$

Hasil berbeda pada penelitian Haryuna (2009) yang mendapatkan persentase tertinggi penderita suara serak ada pada kelompok usia $>60$ tahun, yaitu sebanyak 32 penderita $(29,9 \%)$. Hal ini dikarenakan kasus terbanyak yang dijumpai pada penelitian tersebut adalah keganasan laring yang biasanya lebih banyak dijumpai pada kelompok penderita usia lanjut, sedangkan untuk prevalensi terendah didapatkan pada umur 11-20 tahun yaitu sebanyak 3 penderita $(2,8 \%)^{6}$
Pada penelitian ini didapatkan pasien laki-laki dan perempuan sebanding (1:1) dengan total 34 pasien masing-masingnya (50\%). Penelitian Miller et al (1995) dan Thibealt et al (2004) seperti dikutip dalam Kiakojoury et al (2014) tidak menemukan perbedaan antara jumlah pasien laki-laki dan perempuan. ${ }^{11}$ Penelitian Cohen et al pada tahun 2014 mendapatkan laki-laki $(57,9 \%)$ lebih banyak dariperempuan $(42,1 \%)$, sedangkan penelitian Lundy et al (1998) mendapatkan hasil sebaliknya, yaitu perempuan (54\%)lebih banyak darilaki-laki (46\%). ${ }^{12}$

Berdasarkan hasil penelitian tersebut, dapat disimpulkan bahwa jenis kelamin tidak mempengaruhi kejadian disfonia. Hal ini sesuai dengan literatur yang menyatakan bahwa pengaruh status demografi terhadap kejadian disfonia belum dapat secara pasti ditentukan mengingat banyaknya faktor-faktor yang dapat berpengaruh.

Pada penelitian ini didapatkan bahwa suara serak adalah gejala klinik terbanyak yang diderita oleh keseluruhan jumlah sampel, yaitu sebanyak 68 pasien (100\%). Hal ini sesuai dalam Goldstein et al (2007) yang menyatakan bahwa suara serak merupakan gejala umum pasien disfonia yang menyebabkan pasien mencari bantuan medis. Kelainan dari bentuk atau fungsi pita suara dapat mengakibatkan suara serak. Suara serak juga merupakan gejala awal pada lesi jinak pita suara, penyakit self-limiting seperti infeksi virus ataupun hasil dari suatu proses keganasan atau kanker laring. ${ }^{13}$ Penelitian Jardim et al pada tahun 2007 juga mendapatkan bahwa suara serak adalah gejala klinik yang selalu ada dalam 12 total penelitian epidemiologi gangguan suara terhadap guru $(100 \%) .^{14}$

Pada penelitian ini didapatkan bahwa etiologi terbanyak yang mendasari terjadinya disfonia adalah Laryngopharyngeal Reflux (LPR), yaitu sebanyak 23 pasien $(33,8 \%)$, diikuti oleh paralisis pita suara (23,5\%), dan TB laring (10,3\%). Penelitian Akst et al tahun 2009 mendapatkan etiologi terbanyak pasien disfonia adalah inflamasi yang mencakup LPR, laringitis akut, dan laringitis sicca sebesar $29 \%$, diikuti oleh paralisis pita suara sebesar 19\%, dan phonotrauma yang mencakup nodul, polip, dan kista sebesar $16,5 \%{ }^{15}$ Penelitian Carillo et al (2012) 
mendapatkan tiga hasil terbanyak kelainan laring, yaitu nodul pita suara $(17,4 \%)$, LPR $(16,6 \%)$, dan paralisis pita suara $(12,9 \%) .{ }^{16}$ Penelitian Haryuna (2009) mendapatkan tiga penyebab terbanyak gangguan suara, yaitu keganasan laring (19,6\%), paralisis pita suara $(16,8 \%)$, dan nodul pita suara $(12,1 \%){ }^{6}$ Perbedaan hasil ini disebabkan oleh metode dan jumlah sampel penelitian yang berbeda.

LPR sebagai penyebab terbanyak yang didapatkan pada penelitian ini sejalan dengan penelitian Cohen et al (2012) yang mendapatkan hasil bahwa hampir $50 \%$ pasien dengan gangguan suara terdiagnosis sebagai LPR. ${ }^{17}$ Kiakojoury et al (2014) juga mendapatkan hasil bahwa disfonia organik $(85,78 \%)$ adalah penyebab paling umum dari gangguan suara, diikuti disfonia fungsional $(8,6 \%)$, dan disfonia akibat gangguan neurologik $(5,6 \%){ }^{11}$

Refluks asam lambung ke bagian laring atau Laryngopharyngeal Reflux (LPR) adalah salah satu manifestasi dari Gastroesophageal Reflux (GERD). LPR merupakan salah satu diagnosis yang sering ditetapkan dan sekaligus menjadi kontroversi sebagai penyebab suara serak. Walaupun demikian, LPR harus selalu dipertimbangkan dalam setiap pasien dengan keluhan tenggorok, termasuk suara serak. ${ }^{18}$ LPR sebagai penyakit kronis dengan tampilan yang bervariasi harus diberikan tatalaksana simptomatik yang tepat sampai tereksklusi dari diagnosis. Obat antirefluks yang telah banyak digunakan dalam pengobatan LPR adalah golongan Proton Pump Inhibitor (PPI), seperti omeprazole, lansoprazole, dll. ${ }^{19,20}$

Bentuk lesi terbanyak berturut-turut pada epiglotis adalah hiperemis dan edema, sedangkan pada aritenoid dan plika ventrikularis adalah edema dan hiperemis. Hal ini sejalan dengan penelitian Haryuna (2009) yang menemukan edema dan hiperemis sebagai jenis lesi terbanyak pada pasien disfonia dengan etiologi Tuberkulosis laring yang ditemukan didaerah epiglotis $(66,7 \%)$, aritenoid (50\%) dan plika ventrikularis $(66,7 \%) .{ }^{6}$ LPR sebagai etiologi terbanyak yang didapatkan pada penelitian ini mempunyai gambaran klasik berupa eritema dan edema pada aritenoid, mukosa postcricoid, dan edema pada plika vokalis. ${ }^{13,19}$
Pergerakan plika vokalis yang simetris lebih banyak ditemukan daripada asimetris. Hal ini terkait dengan etiologi bahwa paralisis pita suara dan tumor laring sebagai etiologi terbanyak penyebab terganggunya pergerakan plika vokalis tidak menjadi penyebab terbanyak yang didapatkan dalam penelitian ini. Bentuk lesi terbanyak yang didapatkan pada plika vokalis adalah massa pada sembilan pasien (13,2\%). Hal ini didukung oleh penelitian yang dilakukan oleh Haryuna (2009) yang mendapatkan bahwa keganasan laring adalah temuan terbanyak pada penelitiannya $(19,6 \%)$ yang didapatkan pada daerah supraglotis+glotis $(47,6 \%) .{ }^{6}$

Pada penelitian ini, rima glotis pada umumnya didapatkan terbuka (98,5\%). Rima glotis dalam keadaan tidak sempurna membuka (sedikit tertutup) atau tertutup keseluruhan menandakan adanya parese atau paralisis pita suara yang dapat disebabkan oleh trauma pada nervus laringeal rekuren ipsilateral, trauma setelah operasi daerah tiroid atau thorak, dan neoplasma yang menginvasi atau menekan nervus vagus atau nervus laringeal rekuren. ${ }^{13}$ Standing secretion negatif (-) sinus piriformis pada umumnya didapatkan dalam penelitian ini dikarenakan gejala klinik gangguan menelan tidak menjadi gejala klinik terbanyak yang menyebabkan timbulnya standing secretion positif (+).

Data penelitian yang tidak lengkap mencakup usia, jenis kelamin, gejala klinik, etiologi disfonia, dan gambaran pemeriksaan laring membuat banyak data harus tereksklusi dari sampel penelitian untuk menghindari terjadi bias. Akibatnya, sampel penelitian menjadi sedikit dan membuat hasil penelitian kurang dapat memberikan gambaran yang optimal. Perlu dilakukan studi epidemiologi lebih lanjut terhadap karakteristik pasien disfonia dengan subjek penelitian yang lebih luas sehingga didapatkan hasil yang lebih valid dan representatif.

\section{SIMPULAN}

Etiologi pasien disfonia hampir setengahnya adalah Laryngopharyngeal reflux (LPR). Gambaran pemeriksaan laring pada epiglotis dan plika ventrikularis sebagian besar ditemukan tenang. Pada aritenoid ditemukan edema pada lebih dari setengah 
pasien. Pada plika vokalis ditemukan simetris pada sebagian besar pasien dengan kelainan terbanyak adalah massa. Pada umumnya pada rima glotis didapatkan terbuka dan pada sinus piriformis standing secretion didapatkannegatif (-).

\section{DAFTAR PUSTAKA}

1. Schwartz SR, Cohen SM, Dailey SH, Rosenfeld RM, Deutsch ES, Gillespie MB, et al. Clinical practice guideline: hoarseness (dysphonia). American Academy of Otolaryngology-Head and Neck Surgery. 2009;141(3s2):s1-31.

2. Hermani B, Hutauruk SM. Disfonia. Dalam: Soepardi EA, Iskandar N, Bashiruddin J, Restuti $\mathrm{RD}$, editor (penyunting). Buku ajar ilmu kesehatan telinga hidung tenggorok kepala \& leher. Edisi ke7. Jakarta: Balai Penerbit FKUI; 2012.hlm.209-14.

3. Feierabend $\mathrm{RH}$, Malik SN. Hoarseness in adults. American Academy of Family Physicians. 2009;80(4):363-70.

4. MacKenzie K, Millar A, Wilson JA, Sellar C, Deary IJ. Is voice therapy an effective treatment for dysphonia? a randomised controlled trial. BMJ. 2001;323:658-61.

5. Cohen SM, Kim J, Roy N, Asche C, Courey M. Prevalence and causes of dysphonia in a large treatment-seeking population. The Laryngoscope. 2012;122:343-8.

6. Haryuna TSH. Distribusi gambaran klinik laring pada penderita dengan suara serak di departemen THT-KL Fakultas Kedokteran USU RSUP H. Adam Malik Medan. Majalah Kedokteran Nusantara. 2009;42(1):33-40.

7. Roy N, Stemple J, Merrill RM, Thomas L. Epidemiology of voice disorders in the elderly: preliminary findings. The Laryngoscope. 2007;117:1-6

8. Angelillo N, Costanzo BD, Angelillo M, Costa G, Barillari MR, Barillari U. Epidemiological study on vocal disorders in paediatric age. J Prev Med Hyg. 2008;49:1-5.

9. Hojna BK, Rogowski M, Ruczaj J, Pepinski W, Sitnik AŁ. Diagnosed in the north-east of Poland. International Journal of Occupational Medicine and Environmental Health. 2004;17(2):273-8.
10. Aghadoost O, Shavaki YA, Moradi N, Jalai S. A comparison of dysphonia severity index in female teachers with and without voice complaints in elementary schools of Tehran, Iran. Nurs Midwifery Stud. 2013;2(1):133-8.

11. Kiakojoury K, Dehghan M, Hajizade F, Khafri S. Etiologies of dysphonia in patients referred to ent clinics based on videolaryngoscopy. Iranian Journal of Otorhinolaryngology. 2014; 26(3):16974.

12. Cohen SM, Dinan MA, Roy N, Kim J, Courey M. Diagnosis change in voice-disordered patients evaluated by primary care and/or otolaryngology: alongitudinal study. Otolaryngology-Head and Neck Surgery. 2014;150(1):95-102.

13. Goldstein D, Shrime M, Irish J. Hoarseness: The good, the bad, and the ugly. The Canadian Journal of Diagnosis. 2007:84-8.

14. Jardim R, Barreto SM, Assunção AA. Voice disorder: case definition and prevalence in teachers. Rev Bras Epidemiol. 2007;10(4):625-36.

15. Akst LM, Chaudhary HM, Ishman SL. Spectrum of dysphonia: diagnosis, demographics, and quality of life. Department of Otolaryngology Johns Hopkins Voice Center. 2009.

16. Carrillo RJS, Holgado JWA, Hernandez ML, Tuazon RS. Prevalence of early laryngeal cancer and benign vocal cord pathology among patients undergoing videostroboscopy in Philippine General Hospital from 2008 to 2010. Acta Medica Philliphina. 2012;46(3):18-20.

17. Cohen SM, Kim J, Roy N, Asche C, Courey M. Factors influencing the health care expenditures of patients with laryngeal disorders. Otolaryngology-Head and Neck Surgery. 2012;147(6):1099-107.

18. Mau T. Diagnostic evaluation and management of hoarseness. Med Clin N Am Elsevier Inc. 2001; 94:945-60.

19. Cohen SM, Pitman MJ, Noordzij JP, Courey M. Management of dysphonic patients by otolaryngologists. American Academy of Otolaryngology-Head and Neck Surgery Foundation. 2012;147(2):289-94. 
20. Cobzeanu MD, Voineag M, Drug VL, Ciubotaru A, Cobzeanu BM, Palade OD. Laryngeal morphological changes due to gastroesophageal reflux disease. Rev Med Chir Soc Med Nat Lasi Internal Medicine-Pediatrics. 2012;116(4):1011-5. 